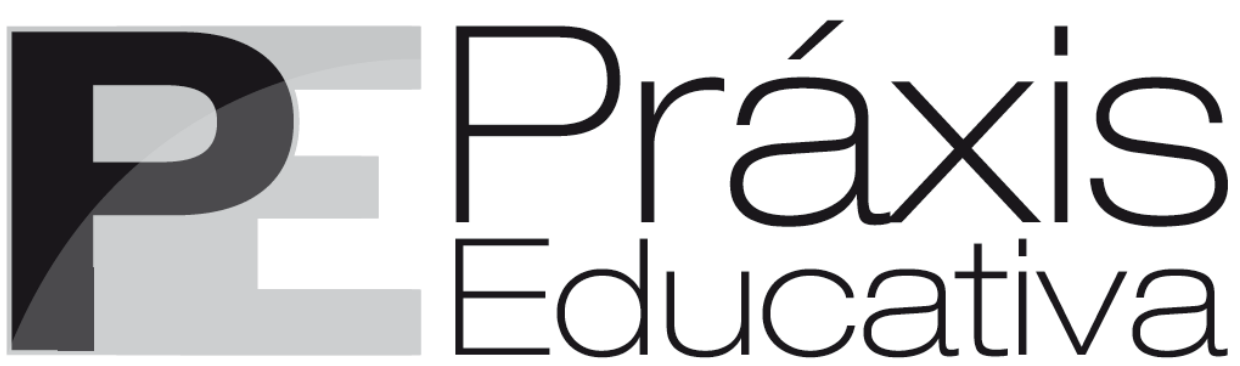

ISSN 1809-4031

eISSN 1809-4309

https://doi.org/10.5212/PraxEduc.v.15.16289.094

\title{
A educação em tempos de COVID-19: ensino remoto e exaustão docente*
}

\section{Education in times of COVID-19: remote teaching and teacher exhaustion}

\section{La educación en tiempos de COVID-19: enseñanza remota y agotamiento docente}

\author{
Karla Saraiva* $^{* *}$ \\ (iD https://orcid.org/0000-0002-2105-0619 \\ Clarice Traversini $^{* * *}$ \\ iD https:/ / orcid.org/0000-0001-6724-2483 \\ Kamila Lockmann ${ }^{* * * *}$ \\ (D) https:/ / orcid.org/0000-0002-1993-8088
}

\begin{abstract}
Resumo: Neste artigo, propõe-se a analisar a trama discursiva que se constitui a partir da necessidade de adaptação das atividades presenciais para atividades remotas no Estado do Rio Grande do Sul durante o distanciamento social causado pela COVID-19. Tomou-se como material empírico a seção de notícias de três sites de sindicatos gaúchos (SINEPE/RS, SINPRO/RS e CPERS/RS), assim como as notícias publicadas na versão online do jornal Zero Hora no período entre o dia 16 de março e 31 de maio de 2020. A pesquisa foi desenvolvida com base na análise do discurso de orientação foucaultiana. A partir da empiria, foram construídos dois eixos analíticos: "Ensino remoto entre oportunidades, dificuldades e desigualdades" e "A docência levada à exaustão". As análises evidenciam o reforço de mecanismos disciplinares, o
\end{abstract}

\footnotetext{
* Pesquisa financiada pelo Conselho Nacional de Desenvolvimento Científico e Tecnológico (CNPq) - Edital Universal.

** Doutora em Educação e Mestre em Engenharia Civil pela Universidade Federal do Rio Grande do Sul (UFRGS). Professora do Programa de Pós-Graduação em Educação e do Curso de Pedagogia da Universidade Luterana do Brasil. E-mail: <profa.karla.saraiva@gmail.com>.

*** Doutora e Mestre em Educação pela UFRGS. Professora da Faculdade de Educação e do Programa de PósGraduação em Educação da UFRGS. E-mail: <clarice.traversini@gmail.com>.

**** Doutora e Mestre em Educação pela UFRGS. Professora do Instituto de Educação e do Programa de PósGraduação em Educação da Universidade Federal do Rio Grande. Bolsista Produtividade em Pesquisa do CNPq Categoria 2. E-mail: <kamila.furg@gmail.com>.
} 
crescimento das desigualdades, algum otimismo com os efeitos de longo prazo e a intensificação do trabalho docente, associada com a possibilidade de contracondutas.

Palavras-chave: Ensino remoto. Escola. Docência. COVID-19. Pandemia.

\begin{abstract}
In this article, we aim to analyze a discursive web established from the need to adapt face-to-face activities to remote activities in the State of Rio Grande do Sul, Brazil, during the social distancing caused by COVID-19. The news section of the websites of three organizations (SINEPE/RS, SINPRO/RS and CPERS/RS), as well as news published in the online version of the newspaper Zero Hora, in the period between March 16th and May 31st, 2020 were taken as empirical material. The research was developed based on a foucaultian orientation of discourse analysis. From the empiric material, two analytical axes were built: "Remote teaching between opportunities, difficulties and inequalities" and "Teaching taken to exhaustion". Analysis shows the strengthening of disciplinary mechanisms, the growth of inequalities, some optimism with long-term effects and the intensification of teaching work, associated with the possibility of counter-conduct.
\end{abstract}

Keywords: Remote teaching. School. Teaching. COVID-19. Pandemic.

Resumen: En este artículo, se propone analizar la trama discursivo que se constituye a partir de la necesidad de adaptación de las actividades presenciales como actividades remotas en el Estado de Rio Grande do Sul durante el aislamiento causado por el COVID-19. Se tomó como material empírico la sección de noticias de tres sitios web de sindicatos de ese Estado (SINEPE/RS, SINPRO/RS e CPERS/RS), así como las noticias publicadas en la versión en línea del periódico Zero Hora en el período entre el 16 de marzo y el 31 de mayo de 2020. La investigación fue desarrollada con base en el análisis del discurso en perspectiva foucaultiana. A partir de lo empírico, fueron construidos dos ejes analíticos: "Enseñanza remota entre oportunidades, dificultades y desigualdades" y "La docencia llevada a la exhaustividad". Los análisis evidencian el refuerzo de mecanismos disciplinarios, el crecimiento de las desigualdades, algún optimismo con los efectos de largo plazo y la intensificación del trabajo docente, asociada con la posibilidad de contra conductas.

Palabras clave: Enseñanza remota. Escuela. Docencia. COVID-19. Pandemia.

\title{
Para iniciar a conversa...
}

A C.F.C. tinha compromissos trabalhistas que Florentino Ariza conhecia melhor que ninguém, tinha contratos de carga, de passageiros, de correio, e muitos mais, incontornáveis em sua maioria. A única coisa que permitia saltar por cima de tudo era um caso de peste a bordo. O navio se declarava de quarentena, içava-se a bandeira amarela e se navegava numa emergência. (MÁRQUEZ, 1995, p. 411).

No ano de 2020, o mundo é paralisado por uma pandemia. Um vírus altamente contagioso e razoavelmente letal provoca uma transformação imaginável na sociedade do 24/7 - vinte quatro horas e sete dias por semana - (CRARY, 2016), que não pode parar, que precisa produzir, que faz tudo para "ganhar um troquinho" (COMITÊ INVISÍVEL, 2018). A sociedade que estava decretando o fim do sono (CRARY, 2016) torna-se insone não pela hiperatividade, mas pelo medo que se instala enquanto todos se isolam em suas casas. Medo da doença, medo do desemprego, medo da falta de renda, medo da fome, medo da violência, medo de um devir que se abre sem quaisquer garantias, medo da certeza crescente de que não voltaremos a ser o que éramos. A pandemia de COVID-19 irrompe de forma abrupta para nos lembrar da fragilidade humana. Contudo, mesmo em meio a essa situação caótica, educar (não) é preciso.

Medidas de isolamento social para reduzir a contaminação são adotadas ao redor do mundo, com maior ou menor rigidez. Quase sempre, as primeiras instituições alcançadas por essas medidas são as educacionais, ambientes que mantêm um grande número de indivíduos confinados juntos por longos períodos. No Estado do Rio Grande do Sul (RS) também foi assim. O governador Eduardo Leite anuncia a suspensão das aulas da rede a partir do dia 19 de março por

Práxis Educativa, Ponta Grossa, v. 15, e2016289, p. 1-24, 2020

Disponível em: <https://www.revistas2.uepg.br/index.php/praxiseducativa> 
meio de um vídeo publicado nas redes sociais em 16 de março (G1 RS, 2020). A prefeitura de Porto Alegre, capital do Estado, também emite Decreto Municipal suspendendo todas as aulas no dia 16 de março (PORTO ALEGRE, 2020a).

Cabe destacarmos que as aulas em quase todas as escolas e universidades privadas do Estado já estavam suspensas desde o dia 16 por recomendação do próprio Sindicato do Ensino Privado (SINEPE). Naquele momento, a previsão era de retomada das atividades no dia $1^{\circ}$ de abril. Contudo, no final de março, o cenário era de ainda maior gravidade, e um Decreto Estadual suspende todas as aulas presenciais até dia 30 de abril (RIO GRANDE DO SUL, 2020a).

Nesse período, não apenas escolas pararam. No dia 17 de março, o município de Porto Alegre, capital do Estado do Rio Grande do Sul, emitiu um Decreto determinando fechamento de shoppings centers, academias, bares e casas noturnas, aumentando o número de restrições no dia 20 (PORTO ALEGRE, 2020b). No dia $1^{\circ}$ de abril, um Decreto Estadual estende as restrições a atividades econômicas a todo Estado (RIO GRANDE DO SUL, 2020b).

Desde o dia 16 de março, as diversas cidades atingidas por Decretos determinando a suspensão de atividades econômicas tornaram-se irreconhecíveis. Somamos às questões legais uma ampla campanha divulgada pela mídia e bem recebida por boa parte da população, repercutindo em redes sociais, exortando a população a ficar em casa, e o azáfama urbano transformou-se em silêncio. Sem lojas, sem academias, sem restaurantes, a circulação de pessoas e veículos reduziu-se a níveis mínimos. Começam a pipocar na imprensa e redes sociais sugestões de atividades para o isolamento: exercícios por meio de orientações online, artesanato, livros, séries, filmes, atividades para crianças. Enfim, alternativas para preencher o tempo vago.

Entretanto, no caso da Educação, a paralisação das atividades nas escolas e nas universidades não significou, necessariamente, um período de folga para professores e alunos. Em algumas redes públicas, a suspensão das atividades presenciais efetivamente traduziu-se na suspensão das atividades de ensino, ainda que em muitas esteja havendo atividades remotas. Contudo, escolas e universidades privadas, inclusive na Educação Infantil, determinaram que as atividades presenciais deveriam ser transpostas, por meio de ferramentas digitais, para um modelo de educação remota enquanto durasse a crise sanitária. Tal decisão recebeu, inclusive, suporte legal do Ministério da Educação (MEC).

Assim sendo, este artigo propõe-se a analisar a trama discursiva que se constitui a partir dessa necessidade de adaptação das atividades presenciais para atividades remotas, com foco no trabalho docente. Pretendemos investigar o que vem sendo dito sobre a docência em tempos de isolamento causado pela COVID-19, no âmbito do Estado do Rio Grande do Sul. Visando a dar conta de uma possível dispersão discursiva, o material empírico da pesquisa foi constituído pelo conteúdo de quatro artefatos: seção de notícias de três sindicatos (um de escolas privadas e dois de professores) e as notícias publicadas na versão online do jornal gaúcho Zero Hora sobre educação no período entre o dia 16 de março e 31 de maio de 2020. Os dados utilizados neste artigo sofreram um corte nessa dada para tornar possível a elaboração do trabalho, porém a produção de dados teve continuidade para subsidiar novas análises.

\section{Percursos metodológicos}

Este artigo assume como perspectiva teórico-metodológica a análise discursiva de orientação foucaultiana. O estudo baseia-se na análise de enunciados presentes nos materiais empíricos, tomando-os como práticas instituidoras de regimes de verdades. Nosso interesse é, portanto, compreender as políticas de verdade que estão sendo produzidas acerca da docência 
durante o período de isolamento causado pela COVID-19. O caráter completamente acontecimental desse evento provocou uma profunda reviravolta na Educação no mundo inteiro, provocando uma paralisação das atividades presenciais que atingem 1,57 bilhão de estudantes, em 191 países, de acordo com a Organização das Nações Unidas para a Educação - UNESCO (2020).

Conforme já colocamos na introdução, para compreendermos os regimes de verdade que vêm se constituindo no RS acerca da docência nos tempos da COVID-19, tomamos como material empírico um conjunto de artefatos midiáticos que consideramos capazes de mostrar uma dispersão discursiva sobre o tema e que compreende quatro artefatos: a seção de notícias do site do Sindicato do Ensino Privado do Rio Grande do Sul (SINEPE/RS), a seção de notícias do site do Sindicato dos Professores do Ensino Privado do Rio Grande do Sul (SINPRO/RS), a seção de notícias do site do Centro dos Professores do Estado do Rio Grande do Sul - Sindicato dos Trabalhadores em Educação (CPERS/RS) e as notícias publicadas na versão online do jornal gaúcho Zero Hora, denominada GAÚCHAZH, sobre educação no período entre o dia 16 de março, quando se inicia a suspensão das aulas, e o dia 31 de maio. Sublinhamos que a pesquisa se encontra em andamento e que o corte de coleta de material e produção de dados deu-se no sentido de permitir a redação deste artigo.

Cabe destacarmos, ainda, que, no dia 27 de maio, o Governo do Estado do RS apresentou um plano de retomada da Educação em cinco etapas (RETOMADA..., 2020). A primeira, que se inicia no dia $1^{\circ}$ de junho, torna obrigatórias as atividades remotas em todas as escolas públicas e privadas. Para as privadas, essa determinação não tem efeito prático, pois, conforme o SINEPE (2020b), já no início de abril, mais de $98 \%$ das instituições de ensino privadas ofereciam atividades remotas. Quanto às escolas públicas, embora muitas já estivessem realizando esforços nesse sentido, não havia um controle muito rígido. Segundo o Decreto, no dia 15 de junho, poderiam voltar as atividades de laboratório nas Universidades e escolas técnicas e alguns cursos livres. As escolas de Educação Básica poderiam retomar suas atividades, na melhor das hipóteses, no dia $1^{\circ}$ de julho, porém isso não foi possível, já sinalizando que o plano não conseguirá ser mantido.

Uma vez selecionados os quatro veículos que iriam constituir a empiria, passamos a acompanhar as publicações nos respectivos sites para compor o corpus da pesquisa. As matérias selecionadas tinham em seu conteúdo referências às formas de organização dos processos de ensino no modo remoto. O Quadro 1 sintetiza a composição do corpus.

Quadro 1 - Composição do corpus

\begin{tabular}{|c|c|}
\hline Veículo & $\begin{array}{c}\text { Número de } \\
\text { matérias }\end{array}$ \\
\hline SINPRO/RS & 4 \\
\hline SINEPE/RS & 14 \\
\hline CPERS & 8 \\
\hline GAÚCHAZH & 18 \\
\hline Total & 44 \\
\hline
\end{tabular}

Fonte: As autoras, 2020.

Dos veículos escolhidos, o site do SINPRO/RS foi o com menor número de matérias, que trataram, em geral, dos direitos dos docentes nas escolas privadas. O site do CPERS foi o segundo em número de reportagens, que mostravam preocupação com as condições de trabalho dos professores, bem como com as dificuldades dos alunos por suas carências. O site do SINEPE/RS teve uma publicação mais regular de artigos, que vão no sentido de mostrar o que as escolas estão fazendo e podem fazer durante o isolamento. No site de GAÚCHAZH, há uma maior abrangência dos temas, tendo em vista não estar ligado a um sindicato. 
Uma vez selecionadas as matérias que comporiam o corpus da pesquisa, foi realizado o primeiro movimento analítico: a definição dos focos de análise. Segundo Saraiva (2009a), a construção de categorias ou foco de análises deve ser realizada a partir de uma análise preliminar da empiria, observadas as recorrências e criando articulações entre os enunciados que constituem os discursos que aí se encontram. Nesse caso, criamos dois focos de análise. O primeiro deles, denominamos "Ensino remoto entre oportunidades, dificuldades e desigualdades". Nesse foco, a atenção estaria sobre os enunciados que tratam de uma certa reinvenção da escola em tempos de pandemia, e as desigualdades que essa reinvenção expõe e amplifica. O segundo foco de análise foi intitulado "A docência levada à exaustão" e discute os limites e as dificuldades que professores enfrentam com os modos de lidar com o tempo e com o corpo durante o período de educação remota, evidenciando, por um lado, a intensificação do trabalho docente; e, por outro, as possibilidades de contraconduta à sociedade 24/7.

A partir da definição desses dois focos de análise, foi realizada uma nova leitura do corpus para a produção de dados para a análise. Durante essa leitura, foram extraídos excertos que dialogavam com os focos analíticos. Esses excertos foram organizados em uma planilha, o que facilitou a construção das análises. Como resultado, foram extraídos 69 excertos relacionados ao primeiro foco de análise e 38 relacionados ao segundo. Cabe esclarecermos que, devido aos limites deste texto, nem todos os excertos e nem todas as matérias estarão presentes no artigo. Nas seções seguintes, são desenvolvidos os dois focos analíticos.

\title{
Ensino remoto entre oportunidades, dificuldades e desigualdades
}

Como já escrevemos antes, o ano letivo de 2020 mal começara no Brasil e as aulas presenciais foram suspensas em função da COVID-19. Aqui e em grande parte do mundo, alunos foram afastados das salas de aula. Todavia, isso não significa afastados da escola.

\begin{abstract}
A Unesco (Organização das Nações Unidas para a Educação, Ciência e Cultura) lançou nesta quinta-feira uma coalizão mundial para assegurar a educação à distância dos mais de 1,5 bilhão de alunos de 165 países afetados pelo fechamento de escolas devido à pandemia do coronavírus. (UNESCO ANUNCIA..., 2020, n.p.). ${ }^{1}$
\end{abstract}

De acordo com Simons e Masschelein (2011), vivemos em um tempo em que aprender tornou-se um imperativo. Para os autores, vivemos em uma sociedade de aprendizagem, que se caracteriza pelo objetivo de produzir sujeitos comprometidos com sua aprendizagem. Os sujeitos que tomam para si a tarefa de aprender continuamente passam a gerir sua vida como uma empresa, tomando a educação como investimento para retornos futuros. Os sujeitos da sociedade de aprendizagem devem tornar-se sujeitos endividados (LAZZARATO, 2011) consigo mesmos, por estarem sempre se sentindo pressionados a ampliar a aprendizagem. Nessa perspectiva, a paralisação dos processos escolares poderia enfraquecer a produção desse comprometimento infindável com a aprendizagem, permitindo a produção de linhas de fuga por parte dos escolares.

Assim como na maioria das localidades de outros países, também no RS se decidiu que a educação não pode parar. Rapidamente, o Conselho Estadual de Educação posicionou-se pela continuidade das atividades escolares fora da escola:

O Conselho Estadual de Educação (CEEd/RS) publicou nesta quarta-feira (18/03) o Parecer $n^{\circ} 01 / 2020$ autorizando as atividades domiciliares na Educação Básica, no

\footnotetext{
1 Neste texto, as citações que fazem parte do material empírico desta investigação serão apresentadas em recuo diferente das citações que dizem respeito ao aporto teórico, assim como as referências do material empírico completas são anunciadas após as referências da base teórica.
}

Práxis Educativa, Ponta Grossa, v. 15, e2016289, p. 1-24, 2020

Disponível em: < https://www.revistas2.uepg.br/index.php/praxiseducativa> 
período de suspensão das aulas presenciais para conter a propagação do coronavírus. (CEED/RS, 2020, n.p.).

Contudo, poucas justificativas aparecem no material empírico para a necessidade de dar continuidade às atividades mesmo com a suspensão das aulas presenciais. Tal questão parece não se colocar, sinalizando a naturalização da ideia de que os processos de escolarização não podem ser interrompidos, ao contrário das atividades produtivas. Indústria, comércio e serviços pararam, mas as escolas não podem parar. A justificativa de que as escolas não podem parar e devem funcionar mesmo que de modo precário seria de evitar danos.

\begin{abstract}
Há consenso entre especialistas que o ensino remoto não substitui o presencial, mas, ao menos, contribui para minimizar os danos causados pela suspensão das aulas. Para o diretor de políticas públicas do Todos Pela Educação, Olavo Nogueira Filho, o afastamento do ambiente escolar deixará sequelas que precisam ser amenizadas mesmo [a] distância. (ELY, 2020, n.p.).
\end{abstract}

A reportagem de onde foi retirado esse excerto, publicada em GAÚCHAZH, não detalha que danos e sequelas haveria. Mencionam-se apenas lacunas na aprendizagem, que parecem que não seriam supridas após um tempo de afastamento da escola. O tempo escolar é um tempo de performatividade e não pode ser desperdiçado, sob ameaça de que não se cumpram determinadas metas. Segundo Ball (2005), a performatividade é uma tecnologia que está impregnada na cultura das sociedades contemporâneas, tendo como princípio a mensuração objetiva do desempenho e da produtividade de indivíduos ou organizações. Ainda de acordo com o autor, a performatividade instala-se na educação, por meio de uma ânsia gerencialista de controlar resultados. Nessa perspectiva, podemos pensar que os principais danos que a suspensão das aulas traria seriam justamente na queda da produtividade educacional.

Uma justificativa encontrada no material empírico para a continuidade das atividades escolares não foi de ordem pedagógica, mas financeira e restrita a escolas privadas. Segundo o SINEPE/RS, as mensalidades devem continuar sendo pagas, tendo em vista que:

Em praticamente todas as instituições de ensino privado do Rio Grande do Sul as aulas estão mantidas por meio das atividades domiciliares. Portanto, segue sendo prestado o serviço educacional. (SINEPE/RS, 2020, n.p.).

No entanto, os primeiros dias após a suspensão das atividades presenciais foram um tanto desconcertantes. O que seriam essas atividades escolares fora da escola? Seria ainda uma escola, manteria ainda a forma escolar? Conforme o excerto anterior, o Conselho Estadual de Educação do RS considerou que seriam atividades domiciliares. Classificação também assumida pelo SINEPE/RS nesse primeiro momento, como mostra o excerto anterior. Entretanto, no dia 17 de abril, surge uma nova expressão: "ensino remoto":

Não estamos fazendo ensino ou educação à distância. Estamos praticando um Ensino Remoto Emergencial. (ENSINO..., 2020, n.p.).

Destarte, para o CPERS, seria, sim, ensino a distância. Em $1^{\circ}$ de abril, uma notícia dá conta de que:

Desde a suspensão das atividades presenciais na rede estadual, educadores(as) e estudantes da rede pública têm participado de um experimento massivo de Ensino a Distância. (EDUCAÇÃO..., 2020, n.p.).

No dia 9 de abril, porém, o CPERS utilizava outra denominação, utilizando o termo "aulas programadas", em alinhamento com a proposta do Governo Estadual: 
As atividades domiciliares, chamadas de aulas programadas durante a pandemia, jamais substituirão o fazer pedagógico com interação presencial. (SAIBA..., 2020, n.p.).

Se o Governo do Estado prefere chamar de "aulas programadas" as atividades escolares que se desenvolvem fora da escola neste período, de modo geral consolidou-se, na mídia, em especial na GAÚCHAZH, a expressão "ensino remoto".

Diversos especialistas têm marcado que ensino remoto e Educação a Distância (EaD) são conceitos distintos (IPOG, 2020). No Brasil, a EaD encontra-se bem disseminada no Ensino Superior. Com pequenas variações, cursos nessa modalidade desenvolvem-se praticamente sem interações síncronas entre professores e alunos, ficando parte significativa do trabalho delegado a um tutor e com avaliações padronizadas. Entretanto, nas escolas privadas, cujos alunos têm amplo acesso à internet e que podem prover soluções educacionais por meio de ferramentas digitais, durante o período de isolamento, têm sido realizadas muitas atividades síncronas. Ao ponto de que algumas escolas, principalmente nos anos finais do Ensino Fundamental e no Ensino Médio, ministrarem aulas por meio do Google Meet ou do Zoom nos mesmos horários que haveria aulas presenciais ${ }^{2}$. Toda a responsabilidade educativa está a cargo do professor, que pode planejar suas avaliações de modo mais personalizado.

No nosso entender, as atividades remotas por meio de ferramentas digitais estão orientadas por uma racionalidade distinta da $\mathrm{EaD}$. Se a $\mathrm{EaD}$ reforça a lógica do controle rizomático, substituindo a vigilância pelas metas (SARAIVA, 2010), o ensino remoto retoma alguns elementos da disciplina. No ensino remoto, é necessário, em geral, um envio de evidências de desenvolvimento de atividades não avaliativas, que funcionam como uma forma de controle do uso do tempo, uma das características da disciplina. $\mathrm{Na} \mathrm{EaD}$, as atividades a serem desenvolvidas são, na maior parte das vezes, avaliações. Os processos de EaD não têm como foco, portanto, o controle do uso do tempo, mas apenas a demonstração de atingimento das metas de aprendizagem, conforme Saraiva e Veiga-Neto (2009).

Além das atividades individuais a serem realizadas, como já mencionamos, frequentemente as escolas que contam com alunos conectados fazem uso de ferramentas de webconferência para ministrar aulas remotas. Essa estratégia reestabelece a noção de um horário a ser cumprido, o que não ocorre na $\mathrm{EaD}$, e torna os corpos visíveis, também funcionando como uma forma de vigilância. Os alunos estão segregados e fixos em seus lugares, com limitadas possibilidades de comunicação. O uso de horários, a fixação dos corpos em espaços celulares e o corte da comunicação são elementos associados aos mecanismos disciplinares. "O espaço das disciplinas é sempre no fundo, celular. Solidão necessária do corpo e da alma", conforme afirma Foucault (1999, p. 123). Solidão, certamente, é o que sentem os alunos impedidos de estarem na escola. Reportagem publicada pela GAÚCHAZH, em 30 de junho, trata de uma ação realizada por escolas privadas de Educação Infantil do município de Canoas, com o objetivo de reduzir essa solidão. Elas

[...] incentivaram os pais a colocarem os pequenos no banco de trás para matar, aos menos por alguns minutinhos, a saudade das profes. A ideia era só acenar de dentro do carro, mas Pedro, Antônio e Helena acabaram desembarcando em frente à escola para conversar - infelizmente, nada de abraços por ora- com a profe Mariane. Voltariam para casa caminhando sorridentes, abanando para a equipe. (FONSECA, 2020, n.p.).

Ainda, em relação ao acionamento de mecanismos disciplinares, é possível observar que, no ensino remoto, a vigilância hierárquica recobre-se com uma nova camada em relação àquela que era mobilizada pelas atividades presenciais: a dos professores e dos alunos pelos pais, tendo em

${ }^{2}$ Informação obtida pelas pesquisadoras por meio de seus contatos informais com professores de Educação Básica.

Práxis Educativa, Ponta Grossa, v. 15, e2016289, p. 1-24, 2020

Disponível em: < https://www.revistas2.uepg.br/index.php/praxiseducativa> 
vista que a sala de aula se desloca para a sala da casa. Em relação aos filhos, os pais passam a desempenhar a função de organizar o horário e de fiscalizar seu cumprimento.

A mãe da estudante, a fonoaudióloga Juliana Leão, percebeu a ansiedade da filha e rapidamente entrou em cena. Ajudou a organizar uma tabela de horários e diluir as tarefas ao longo da semana. (EDUCAÇÃO A DISTÂNCIA..., 2020, n.p.).

Rita sincronizou seu próprio smartphone com o despertador e a agenda do celular do filho e alinhou o período de tarefas de ambos, com intervalos, refeições e pausas combinados. Desta forma, reforçou a disciplina de horários e colocou uma trava em um eventual exagero no uso de tecnologia. (EDUCAÇÃO A DISTÂNCIA..., 2020, n.p.).

Os vigias multiplicam-se e ganham competências punitivas. Tanto os pais podem aplicar sanções em seus filhos, caso considerem que não estejam agindo adequadamente, quanto poderão fazer solicitações junto às escolas, se considerarem os procedimentos utilizados pelos docentes inadequados. Há relatos de pais pedindo a redução das atividades e outros pedindo o aumento ${ }^{3}$. De qualquer modo, quando a escola entra na sala da casa, dissolvem-se os muros e os professores ficam expostos ao olhar das famílias.

A biomédica Evelyn Navarro disse que seu filho Vitor, 4, espera ansiosamente todos os dias pelos vídeos dos professores. Para ela, a escola deveria oferecer mais gravações, mesmo com atividades parecidas ou que não abordem conteúdos escolares. (EDUCAÇÃO A DISTÂNCIA..., 2020, n.p.).

O trabalho em parceria pressupõe conhecer e respeitar as especificidades do papel desempenhado por cada um no contexto de educar. "Muitos ruídos na comunicação residem no fato de os pais não conhecerem a rotina e a organização dos tempos e espaços da educação. E a escola, por sua vez, precisa propiciar maneiras de esses pais serem mais ativos e conhecerem tal organização", revela o pedagogo. "A família precisa confiar nos profissionais que atuam na escola e estar disponível para os momentos em que seja acionada. Pais e escola têm sempre um objetivo em comum: a educação, que só ocorrerá com efetividade se ambos estiverem em sinergia e integração" (FILHOS..., 2020, n.p.).

De acordo com Han (2018, p. 9), “[...] nos dias atuais não há mote que domine mais o discurso público do que o tema da transparência". Para o autor, a transparência que permite que tudo seja visto e nada está oculto torna os processos rasos, operacionais e orientados para a avaliação externa. Ao contrário do que possa parecer, a transparência não cria confiança, mas destrói a confiança. A exigência de que se elimine toda a zona de sombra e que não haja nada de que não se saiba não deixa espaço para a confiança, que significa construir uma relação com o outro apesar das lacunas no saber. A excessiva exposição dos docentes causa cansaço e tem potencial para destruir os laços de confiança, já um tanto desgastados por movimentos como o Escola sem Partido.

Desse modo, consideramos que a educação remota tem fortalecido mecanismos disciplinares. Outro elemento que reforça a ideia de que a educação remota está orientada por princípios disciplinares é a ênfase dada à questão dos conteúdos. Em tempos de COVID-19, parece que as discussões sobre currículo que vêm sendo desenvolvidas nas últimas décadas e que consolidam um entendimento de que a escolarização não pode ser resumida à aprendizagem de conteúdos estão sendo atropeladas.

Cada um dos 42 mil professores da rede estadual pode dar aulas como achar melhor. O governo criou uma metodologia chamada Aulas Programadas, que são atividades de revisão, online ou distribuídas em apostilas impressas, cujas respostas serão entregues na

\footnotetext{
${ }^{3}$ Essas informações também foram obtidas pelas pesquisadoras por meio de seus contatos informais com professores de Educação Básica.
} 
volta das aulas presenciais. Em muitos casos, o material é deixado na escola para os pais - em regiões rurais, segundo a Seduc, a família recebe em casa. (HARTMANN; BOFF, 2020 , n.p.).

Para Eizerik, o importante nesse momento é a preservação da vida. "Tão logo se normalizem as atividades presenciais, as instituições irão trabalhar na oferta e revisão dos conteúdos que não foram aprendidos pelos alunos" comenta. (MEDIDA..., 2020, n.p.).

Se $97,4 \%$ dos estudantes da rede privada gaúcha aprendem conteúdos novos diariamente, alunos da rede estadual apenas revisam atividades - quando têm acesso à internet. $(97,4 \% \ldots, 2020$, n.p.).

Os processos de escolarização fortemente disciplinares são centrados em conteúdos e planejamentos rígidos. Para o SINEPE/RS, nem mesmo o isolamento deveria causar impacto sobre isto, pois

[...] nesse novo formato, o que muda são os recursos para ministrar a aula (já que não são possíveis os encontros presenciais), mas o professor segue seu planejamento. (SINEPE/RS, 2020, n.p.).

Ainda que não componha a empiria, gostaríamos de destacar que o retorno às atividades presenciais em escolas em outros países, bem como o protocolo recomendado pelo Conselho Nacional de Secretários de Educação (CONSED, 2020), também reforçam a disciplina escolar, pois preveem que os alunos deverão ficar fixos em seus lugares e deverão evitar contato com colegas, não sendo aconselhável a realização de trabalhos em grupo. A sala, mesmo na Educação Infantil, deverá configurar-se de modo rígido, distribuindo as mesas em filas e colunas. Além disso, diariamente os alunos passarão por um exame, com medição da temperatura corporal, para poderem entrar na escola.

É importante observarmos que o modo como a sociedade tem lidado com o vírus também tem traços fortemente disciplinares, como os já apontados por Foucault (2008). O autor apresenta três modos de lidar com doenças: o modelo da lepra, que exclui o doente da cidade, relacionado ao poder soberano; o modelo da peste, que enclausura os sujeitos em suas residências, relacionado ao poder disciplinar; e o modelo da varíola, que, por ter uma vacina, permite a livre circulação, associado a mecanismos de segurança biopolíticos. Assim como na peste, estamos confinados em casa, ainda que esse confinamento seja analisado a partir de argumentos científicos baseados em evidências estatísticas para avaliação do risco, um traço dos mecanismos de segurança.

Em nossas sociedades, como esse mesmo autor afirmou em uma entrevista (FOUCAULT, 2006), os mecanismos disciplinares estariam perdendo força. Saraiva e Veiga-Neto (2009), entre outros autores, já mostraram que o enfraquecimento das disciplinas pode ser percebido tanto na organização das atividades produtivas, quando nos processos educacionais. Esse súbito retorno a uma disciplina muito restritiva à circulação e que regulamenta fortemente as atividades econômicas causa incômodo em uma sociedade que se acostumou a ter mobilidade como um valor e a assumir liberdade como a possibilidade de agir de acordo com seus interesses. Nesse sentido, é possível compreender a forte resistência de segmentos da sociedade ao isolamento como um estranhamento, um atrito com o que consideram normal e aceitável. A saída para a crise sanitária está na produção de uma vacina, que permitiria passar do modelo da peste para o modelo da varíola. Desse modo, permitiria abrandar os mecanismos disciplinares em favor de mecanismos de segurança.

Contudo, se é possível perceber um reforço nos mecanismos disciplinares, também chama atenção os muitos artigos que saúdam o isolamento como uma forma de acelerar o afastamento da escola dos modelos tradicionais, promovendo inovações e incentivando a autonomia dos alunos. 
Pelo menos dois artigos veiculados no site do SINEPE/RS apresentam uma visão de que a pandemia seria uma oportunidade para rápidos avanços:

De forma emergencial e com pouco tempo de planejamento e discussão (o que levaria meses em situação normal), professores e gestores escolares, público e privado, da educação básica a superior, tiveram que adaptar in real time (em tempo real) o currículo, atividades, conteúdos e aulas como um todo, que foram projetadas para uma experiência pessoal e presencial (mesmo que semipresencial), e transformá-las em um Ensino Remoto Emergencial totalmente experimental. Fazendo um recorte desse processo, podemos afirmar que nunca a educação foi tão inovadora. Foi a transformação digital mais rápida que se tem notícia num setor inteiro e ao mesmo tempo. (ENSINO..., 2020, n.p.).

Realmente acredito que o ensino remoto emergencial vai nos ensinar a ser a escolas que sempre sonhamos e nunca pensamos ser possível construí-la. Uma escola que experimenta, que aprende, que inova, que tenta o novo, e sempre busca o melhor para o ator mais importante deste processo e a razão da escola ou IES existir, o aluno e seu ganho de aprendizagem. (ENSINO..., 2020, n.p.).

GAÚCHAZH também trouxe reportagens que apontam um possível legado positivo para o campo educacional:

De uma hora para a outra, logo no início de um ano letivo, professores que nunca tinham gravado conteúdo online estavam à frente das câmeras dos próprios celulares. Estudantes descobriram um mundo de lições na internet e perceberam que podem aprender bastante mesmo fora da sala de aula. Pais ficaram sabendo que podem encontrar propostas educativas, com vídeos ou transmissões ao vivo, até para as crianças pequenas. (JUSTINO, 2020, n.p.).

É possível perceber nesses excertos uma ênfase no uso das tecnologias digitais, tomandoas como sendo uma inovação tecnológica. A "educação que sempre sonhamos" se renova por substituir a aula presencial, muitas vezes taxada de obsoleta, por um vídeo? A inovação se dá pelo uso de uma plataforma digital, como o Moodle e o Classroom? O que difere realizar atividades nessas plataformas do antigo "tema de casa"? Nesse sentido, parece-nos que esses enunciados estão baseados em um tecnicismo educacional, que considera que a introdução de recursos tecnológicos na educação seja algo benéfico e inovador por si mesmo.

Entretanto, alguns especialistas também sinalizam mudanças que estariam relacionadas às novas posturas dos estudantes:

E está justamente nessa superação dos desafios impostos atualmente o caminho apontado por educadores para levar a um possível novo patamar o ensino no Brasil, espelhado em modelos que já vigoram em países que são exemplos em educação. [...]. Esses novos modelos de educação demandam participação ativa do aluno, garantindo mais autonomia mas também cobrando maior comprometimento. (JUSTINO, 2020, n.p.).

Para Khan, as crianças têm muito a perder com escolas fechadas, da socialização ao próprio conhecimento, no caso das mais pobres. Mas podem sair com algo a mais disso tudo: autonomia para aprender. (JOVENS..., 2020, n.p.).

Esses dois excertos apresentam a ideia de que a pandemia seja um momento que os alunos podem aprender a ser mais autônomos, trazendo benefícios duradouros. Conforme Saraiva e Veiga-Neto (2009), a valorização da autonomia por parte dos estudantes estaria relacionada à racionalidade neoliberal que se espraia pelas sociedades desde o final do século XX e que tem como um de seus pressupostos tornar os sujeitos empresários de si mesmos, com autonomia para gerir sua vida. 
Contudo, no último excerto, Salman Kahn, o conhecido fundador da Academia Kahn, instituição que disponibiliza vídeos educativos gratuitos online, chama atenção para o crescimento das desigualdades. Essa questão esteve bastante presente nas discussões sobre educação remota nestes meses iniciais de isolamento social. Para além da discussão sobre as vantagens e as desvantagens da utilização de ferramentas digitais, um tema recorrente tem sido a dificuldade de trabalhar de modo remoto em escolas públicas pela falta de recursos dos alunos. Tal fato está acentuando as desigualdades já gigantescas entre escolas públicas e privadas.

Já no dia 2 de abril, o site do SINEPE/RS noticiava:

98,4\% das instituições estão trabalhando com atividades domiciliares. (MEDIDA..., 2020, n.p.).

No dia 30, do mesmo mês, foi publicada a seguinte informação:

A interação entre professor e aluno é promovida por todas as escolas que participaram da pesquisa e 78,6\% delas fazem uso de mensagens de texto e vídeos para esse fim. Em $61,1 \%$ das instituições, a comunicação é diária; em 33,6\% ocorre em dias intercalados e $4,6 \%$ das escolas promovem o contato apenas quando os alunos solicitam. $(97,4 \% \ldots$, 2020 , n.p.).

Nessa mesma reportagem, o SINEPE/RS anunciava:

$97,4 \%$ das escolas privadas usam plataformas online e aplicativos para o ensino remoto. $(97,4 \% \ldots, 2020$, n.p.).

Já GAÚCHAZH noticia, no dia 29 de abril, que:

Em vulnerabilidade social, parte dos alunos das redes municipais e estadual não tem acesso à internet. Por isso, cada professor tem usado seu próprio método - livros, cadernos, grupos de WhatsApp, páginas no Facebook e blogs -, enquanto a Secretaria da Educação do RS é cobrada para unificar processos. (ELY, 2020, n.p.).

O site do CPERS, em uma publicação datada do dia 28 de abril, traz uma matéria em que são entrevistados representantes dos estudantes. Nas falas, destaca-se a questão da desigualdade.

"Sabemos que os estudantes de colégio particular e estadual não estão no mesmo patamar. Que não é justa a competição entre educandos de escolas privadas e públicas e agora está mais injusta ainda. Não é justo os mais vulneráveis pagarem a conta nesse momento de pandemia", declarou Alice Gaier Viario, $1^{\mathrm{a}}$ vice-presidente da UEE RS. Já a presidente da União Metropolitana dos Estudantes Secundários de Porto Alegre (UMESPA), Vitória Cabreira destacou que tem milhares de estudantes secundaristas desassistidos no RS, não só com a falta de internet e computador, mas com a falta de alimento. "Chegaram até nós relatos de estudantes que não estão comendo. E quem tem fome tem pressa. Precisamos que essas cestas que o governo falou que seriam distribuídas sejam entregues rápido em todo Estado", afirmou. Vitória também falou do descaso do governo com os professores. (EM AUDIÊNCIA..., 2020, n.p.).

Esse excerto expõe que a desigualdade e as dificuldades enfrentadas pelos alunos de escolas públicas não podem ser resumidas à questão de acesso à internet. Os alunos mais carentes, que não podem desfrutar da merenda escolar, estão passando fome. Outra reportagem publicada em GAÚCHAZH reforça essa ideia, ao afirmar que

[...] a desigualdade de condições interfere, inclusive, no esforço de estudar. Em um contexto no qual muitos alunos vão à escola para comer, ter um silencioso cômodo da casa com computador para se concentrar é para poucos. (HARTMANN; BOFF, 2020, n.p.).

Práxis Educativa, Ponta Grossa, v. 15, e2016289, p. 1-24, 2020

Disponível em: <https://www.revistas2.uepg.br/index.php/praxiseducativa> 
No entanto, para o presidente do SINEPE/RS, essa desigualdade não pode onerar as escolas privadas:

O presidente do Sinepe, Bruno Eizerik, diz que escolas privadas são mais rápidas em implantar medidas sanitárias, o que permite a retomada antes. [...].. "Entendo que o Estado não tenha condições em implementar um protocolo em curto espaço de tempo. Mas se a rede privada consegue implementar, seria injusto que esses alunos não voltem à escola”. (HARTMANN; BOFF, 2020, n.p.).

Neste momento, é possível perceber que as políticas públicas de inclusão digital que vêm sendo desenvolvidas desde os anos de 1990 não foram eficazes. Conforme Saraiva e Santos (2009), a inclusão digital no Brasil deu-se por meio de ações cujo lócus eram as escolas. A última iniciativa nesse sentido foi o Programa Educação Conectada, lançado em 2017, que tem por objetivo equipar escolas com internet de alta velocidade. Agora, constata-se que a internet torna-se realmente necessária quando os alunos não podem ir à escola. Para contornar essa dificuldade:

De uma sugestão do deputado Gabriel Souza (MDB) nasceu uma das iniciativas mais importantes da Assembleia Legislativa neste ano: a oferta de internet para que alunos da rede pública estadual possam ter aulas à distância. Os deputados concordaram em abrir mão de mais $\mathrm{R} \$ 5,4$ milhões do orçamento do Legislativo neste ano para financiar a oferta de banda larga no celular de professores e de estudantes que estão sem aulas presenciais desde 19 de março. O dinheiro será liberado em parcelas, ao longo de 12 meses. (OLIVEIRA, 2020, n.p.).

Entretanto, essa iniciativa pode ser vista como uma in/exclusão (VEIGA-NETO; LOPES, 2011), uma vez que os alunos não teriam acesso completo à internet.

Para que as crianças e adolescentes não gastem o pacote de internet com jogos ou conteúdos inadequados, as operadoras têm condições técnicas de colocar travas que limitem o uso do às atividades escolares. (OLIVEIRA, 2020, n.p.).

A vulnerabilidade social em que se encontram esses alunos não lhes dá direito a um amplo acesso à rede. A infância e a juventude pobre devem ser tuteladas e controladas pelo Estado, como já tem sido historicamente no Brasil. De acordo com Rizzini (2011, p. 225), desde o Brasil colônia, existe uma preocupação com os "menores vadios, vagabundos, viciosos e delinquentes", prevendose formas de evitar a vagabundagem e inserir esses sujeitos no mundo do trabalho. Percebe-se aqui a continuidade dessa concepção, em que a vagabundagem se transforma em acesso a conteúdos que não os estritamente educacionais.

A educação remota vem trazendo questões e desafios para a Educação Básica e para a docência, mas, mesmo com todas as dificuldades, não se coloca em questão a paralisação dessas atividades. Insegurança, necessidade de adaptações rápidas, invasão da casa pelo trabalho e pela escola, ansiedade frente às condições sanitárias e econômicas são elementos presentes no cenário atual que vêm produzindo professores em estado de exaustão.

\section{A docência levada à exaustão}

Quem já viveu na costa oeste da América do Norte deve saber que, em função das estações, todo ano centenas de espécies de pássaros migram para o Norte e para o Sul, perfazendo distâncias variadas ao longo da plataforma continental. O pardal de coroa branca é uma dessas espécies. No outono, eles voam do Alasca até o norte do México, na primavera voltam para o Norte. Diferentemente da maioria dos outros pássaros, esse pardal tem uma capacidade extraordinária de permanecer acordado por até setes dias durante as migrações, o que lhes permite voar e navegar a noite, e procurar por alimento de dia, sem descansar. (CRARY, 2016, p. 11).

Práxis Educativa, Ponta Grossa, v. 15, e2016289, p. 1-24, 2020

Disponível em: <https://www.revistas2.uepg.br/index.php/praxiseducativa> 
Poderíamos pensar que estamos vivendo em um período de migração e, tal como o pardal de coroa branca, os professores precisam desenvolver essa capacidade extraordinária de trabalhar em um regime de 24/7, como anuncia Jonathan Crary (2016), em seu livro O capitalismo tardio e os fins do sono. Para o autor, o regime $24 / 7$ expõe a inscrição generalizada da vida humana em uma rotina de funcionamento contínuo. Tal regime torna plausível, e até mesmo normal, a ideia do trabalho sem pausa, da produtividade sem limites e de uma disponibilidade quase absoluta às demandas do tempo presente, sejam elas vinculadas ao trabalho profissional ou ao trabalho doméstico. O autor destaca ainda que "[...] essa suspensão da vida não revela o custo humano exigido para sustentar sua eficácia” (CRARY, 2016, p. 18).

Os excertos a seguir deixam evidente uma espécie de trabalho contínuo e de disponibilidade irrestrita a que estão sendo submetidos professoras e professores da Educação Básica. Tal trabalho em regime 24/7 fica evidenciado em alguns enunciados materializados nas notícias:

Segundo Cecília, os relatos mais frequentes dos professores expressam um volume de
trabalho para além da carga horária contratada, o não fornecimento de equipamento por
parte da instituição e o excesso de demandas. [...]. E destaca: "Estamos todos vivendo
uma situação inusitada no país e no mundo. É grave. Os professores também estão
abalados e tendo que se adaptar à realidade, assim como os estudantes e suas famílias".
(OCHÔA, 2020, n.p.).

Uma professora que pede para não ser identificada relata: "o governo não se deu conta que temos que planejar, postar a sequência das aulas para nossos alunos, estar disponíveis para atender e explicar individualmente no watts, ter tempo para receber as atividades e corrigir, preencher planilha no e-mail, no diário online e físico e procurar aulas online para que nossos alunos tenham o melhor conhecimento possível. E, com tudo isso, ainda nos obriga a fazer um curso on-line com prazo para entregar provas?". (CANSAÇO..., 2020, n.p.).

Comunidades escolares se organizaram para lidar com os obstáculos. Além das apostilas, cada uma das 12 turmas da Escola Antão de Faria, no Bairro Bom Jesus, zona leste da Capital, tem um grupo de WhatsApp - há outro exclusivo para pais e professores. Os docentes estão disponíveis para responder nos três turnos do dia, segundo a faxineira desempregada Caroline dos Santos, 31 anos: - O professor tá sempre online, tira todas as dúvidas. Dia e noite, eles nos ajudam sempre. (HARTMANN; BOFF, 2020, n.p.).

O material empírico mostra repetidas vezes uma demanda por disponibilidade irrestrita dos professores nesses tempos de pandemia. O trabalho vai além da carga horária contratada e o professor encontra-se disponível nos três turnos para responder às perguntas e tirar dúvidas por Whats App. Além disso, há a necessidade de planejar as atividades, enviar, seja em formato digital ou físico, e, ainda, ter tempo para receber e corrigir as atividades realizadas pelos alunos.

Tudo isso evidencia não só esse regime de trabalho 24/7, mas também a configuração de um outro modo de organizar os processos escolares que foi denominado por Lockmann e Traversini (DIÁLOGOS..., 2020) de escolarização delivery. Com isso, as autoras tentam evidenciar um tipo de escolarização que emerge na pandemia e organiza-se a partir de uma lógica que dissocia o planejamento da execução. A escola e os professores pensam e planejam determinadas atividades e entregam tais atividades à família que fica responsável pela sua execução. Uma espécie de escolarização à domicílio ou a pronta entrega que parte da premissa de elaborar, planejar e organizar atividades que podem ser entregues à família e serão por ela desenvolvidas. Por mais que existam algumas escolas que consigam promover momentos de encontro digital, por meio do uso de diferentes plataformas, esse modelo é reservado a uma minoria, como mostramos na seção anterior. Assim, a maior parte das escolas, em especial as escolas públicas, têm se organizado a partir dessa lógica da escolarização delivery, por mais que usem para isso uma variedade de recursos: atividades 
em folhas, impressas pela escola e encaminhada às casas dos estudantes, produção de vídeo enviados por WhatsApp, Facebook, blog da escola.

Um aspecto importante que nos parece necessário de discutir aqui é a compreensão de que essa escolarização em domicílio é movida por um sentimento de que não podemos perder tempo, de que não podemos parar! O texto do coletivo Pansophia Project (2020) - Onæe teses urgentes para uma pedagogia do contra-isolamento - convida-nos a um breve exercício de imaginação. Ele traz:

\begin{abstract}
Se o mesmo vírus tivesse sido desencadeado 20 anos atrás — e sabemos que 20 anos não é nada - o COVID-99 nos encontraria em quarentena com rádio, TV a cabo, conexões à Internet principalmente por telefone (para a minoria conectada) e telefones celulares com tampinha. Sem plataformas, sem redes sociais, sem vídeos sob demanda, sem streaming ou videochamadas e com uma web ainda acordando O que teríamos feito em $1999 \mathrm{com}$ a educação escolar? Como em situações semelhantes (terremotos, epidemias, guerras, inundações), certamente teríamos assumido a perda de avançar para planejar o retorno às escolas. (PANSOPHIA PROJECT, 2020, n.p.).
\end{abstract}

Os autores continuam afirmando que hoje, a partir da cultura digital em que nos encontramos imersos, temos a sensação de que perderemos menos, ou que não perderemos diretamente: "Em virtude desse culto ao imediatismo, rapidamente nos colocamos a fornecer soluções imediatas para continuar a educação" (PANSOPHIA PROJECT, 2020, n.p.), ou, ainda, em produzir essa forma de escolarização em domicílio, a pronta entrega ou delivery.

Conforme já referimos, o trabalho docente "[...] abarca tanto os sujeitos nas suas complexas dimensões, experiências e identidades quanto as condições em que as atividades são realizadas no ambiente escolar" (ASSUNÇÃO; OLIVEIRA, 2009, p. 353). Exige um tempo para cumprir suas responsabilidades que não se limita no período de regência de classe. Essa condição é bastante conhecida, pesquisada e tornada pauta de reivindicações nas negociações salariais, de reconhecimento e de valorização profissional. Entretanto, desde a década de 1990, com as reformas educativas globalizadas, houve um processo de intensificação do trabalho docente (APPLE, 1995; HARGREAVES, 1998; GARCIA; ANADON, 2009). Processo composto por duas facetas: por um lado, "[...] a intensificação pela ampliação das demandas profissionais na vida das professoras, impelidas desde uma perspectiva administrativa e burocrática [...] " (GARCIA; ANADON, 2009, p. 69); e, por outro, a "[...] autointensificação, pela exploração do sentimento de profissionalismo das professoras e de suas autoimagens calcadas no cuidado e no zelo que caracterizam historicamente a educação da infância" (GARCIA; ANADON, 2009, p. 69)

Em nossos materiais empíricos, as instâncias sindicais externam a preocupação com a intensificação e autointensificação do trabalho docente e orientam os docentes sobre o assunto. $\mathrm{O}$ CPERS/RS e o SINPRO/RS manifestaram-se quanto às condições oferecidas pela mantenedora de trabalho para a oferta de educação remota:

A Seduc e as CRES precisam assegurar recursos técnicos e financeiros mínimos para a realização do trabalho. Há educadores(as) sem dinheiro para comer tirando do próprio bolso para arcar com dados móveis. A carga horária por vezes supera a do período presencial. A formação continuada tem sido um vetor de crise e ansiedade. É inadmissível que, em um momento que pede tranquilidade, segurança e boa saúde, as atividades docentes gerem tanto estresse, aflição e sobrecarga para educadores(as) e estudantes. (ATIVIDADES..., 2020, n.p., grifos nossos).

Diante disso, o CPERS recomenda:

1. Não trabalhe fora do seu horário normal;

2. Não responda pais ou alunos fora do seu horário normal;

3. Não faça os cursos de formação continuada fora do seu horário normal;

Práxis Educativa, Ponta Grossa, v. 15, e2016289, p. 1-24, 2020

Disponível em: <https://www.revistas2.uepg.br/index.php/praxiseducativa> 
4. As direções devem comunicar claramente à comunidade escolar os horários disponíveis para o atendimento aos alunos e a realização de aulas programadas;

5. Quaisquer dificuldades na realização das aulas programadas ou do curso devem ser registradas e comunicadas à direção das escolas e às CREs;

6. Não peça fotos dos alunos estudando ou fazendo trabalhos, nem faça prints de webconferências. Expor imagem de menores é uma violação do ECA;

7. As CREs e direções devem respeitar as múltiplas realidades e limitações de cada escola, educador(as) e estudante (ATIVIDADES..., 2020, n.p., grifos nossos).

O Sinpro/RS destaca que a suspensão das aulas presenciais não dispensa os professores do cumprimento de demandas que objetivem a continuidade das atividades letivas. Mas destaca que esta circunstância não autoriza as instituições de ensino a extrapolarem as exigências de trabalho para além da carga horária normalmente dispendida nas condições normais de funcionamento (SINPRO/RS, 2020, n.p., grifo nosso).

Conforme os dois primeiros excertos anteriores, a falta de formação e de infraestrutura adequada de acesso para realizar atividades remotas com os estudantes em plataformas virtuais afeta um número significativo de professores que atuam na rede pública da Educação Básica, gerando estresse e ansiedade. Para Saraiva (2009b, p. 3): "A EaD torna possível um novo tipo de sequestro: já não o corpo enclausurado, mas o tempo utilizado". A autora problematiza a EaD, mas parece-nos adequado estender suas análises para a educação remota. Os professores já não têm a obrigação de deslocar-se até a escola e cumprir horários tão rígidos, mas isso está longe de significar uma redução do trabalho. O ensino remoto, "[...] ao mesmo tempo em que libera os sujeitos do cumprimento de horários, os mantém em um comprometimento permanente" (SARAIVA, 2009b, p. 4). Ainda de acordo com a autora, "[...] a comunicação ilimitada entre professores e alunos é muito mais do que um recurso para melhorar a aprendizagem. É uma estratégia de controle mútuo permanente e um modo de aprender novos significados espaçotemporais e novas maneiras de ser e estar no mundo" (SARAIVA, 2009b, p. 6).

Guimarães e Souza (2020, p. 1), professores da Rede Estadual do Paraná, em artigo em que discutem a docência em tempos de isolamento nesse Estado, ainda acrescentam a esses problemas o "[...] desconto de falta em folha de pagamento para o docente que não acompanhar as atividades de educação a distância" e também mostram a intensificação do trabalho docente. Estudos como esse evidenciam que tais condições são recorrentes nas redes públicas de ensino de outros Estados brasileiros. Silva (2020, p. 73) pondera que existe o risco de precarização permanente do trabalho docente "[...] caso não façamos as devidas críticas ao processo de sofrimento, pelos quais muitos e muitas de nós, profissionais do ensino, têm passado, durante a pandemia". A própria recomendação do CPERS/RS de que os docentes realizem as atividades no horário normal, isto é, "dentro" da carga horária de trabalho, são indícios que o 24/7 está em curso.

As recomendações dos sindicatos na direção de conter a intensificação e autointensificação do trabalho docente são lidas/significadas neste artigo como práticas de contraconduta. Entendemos essa noção a partir de Foucault (2008), que, ao discutir as formas de resistência nas diferentes épocas históricas, mostra seus deslocamentos fazendo emergir a contraconduta. A noção é compreendida como "[...] luta contra os procedimentos postos em prática para conduzir os outros” (FOUCAULT, 2008, p. 266).

Como mostraram Traversini, Lockmann e Goulart (2019 p. 1575), a contraconduta não pode ser considerada "[...] sinônimo de resistência, uma vez que não se trata de oposição, de enfrentamento a formas de governamento específicas". As autoras mencionam que, em vez disso, a contraconduta é "[...] 'dar às costas' a um tipo de condução para exercer outras formas de se conduzir, consideradas produtivas a determinados modos de vida" (TRAVERSINI; LOCKMANN; GOULART, 2019, p. 1575). As autoras mencionam quatro dimensões que caracterizam a contraconduta: "[...] não aceita passivamente determinados modos de condução 
praticados, adquire uma conotação ativa, tem relação com o comum e pode ser compreendida como uma atitude crítica" (TRAVERSINI; LOCKMANN; GOULART, 2019, p. 1574).

As informações coletadas mostraram-nos a preponderância de uma das dimensões: a relação entre contraconduta e atitude crítica. A atitude crítica caracteriza-se como uma "[...] inquietude em torno da maneira de governar" (FOUCAULT, 1990, p. 3), que questiona os modos como somos conduzidos pelas diferentes práticas instituídas (COSTA, 2019). Então, os modos de condução dos professores, neste momento de pandemia, pelos sindicatos, parecem encaminhar ações para "frear" o uso do tempo fora do "horário normal" para exercer as atividades. São outras práticas de condução que "dão as costas" para o tempo ilimitado no exercício do ensino remoto. São assumidos modos de conduzir e conduzir-se que, dada a contingência do momento, exigem atenção à vida cotidiana do professor e a sua família, que assim como qualquer pessoa vive o isolamento social. Exigências na priorização dos cuidados com sua vida e a dos outros. A atitude crítica possibilita mover outros modos de condução frente às exigências das mantenedoras que podem se materializar em dar limites ao tempo de trabalho, exercer as ações com mais vagar e acolher o estudante nas suas singularidades e não priorizar somente as atividades escolares remotas. Tais práticas parecem poder auxiliar a lidar com a intensificação e a autointensificação do trabalho docente na pandemia. Não se trata aqui de "cruzar os braços" (resistir e não fazer), mas, sim, de "dar as costas" (fazer de outros modos) para a chamada recuperação das aulas.

No início da pandemia no Brasil, quando as escolas públicas do RS suspenderem as atividades em meados de março do corrente (2020), havia a expectativa de recuperação presencial das aulas nas escolas públicas gaúchas, conforme a "Nota conjunta de esclarecimento FAMURS, UNDIME/RS E UNCME-RS", em 27 de março (FAMURS; UNDIME; UNCME, 2020) e foi tema da reportagem a seguir, em 2 de abril:

A Federação das Associações dos Municípios do Rio Grande do Sul (Famurs), União Nacional dos Dirigentes Municipais de Educação (Undime/RS) e União Nacional dos Conselhos Municipais de Educação do Rio Grande do Sul (Uncme-RS) defendem que as aulas sejam recuperadas de forma presencial. (ENTIDADES..., 2020, n.p.).

Quando trazemos esse tipo ação, estamos privilegiando um tipo de aluno. O nosso objetivo é garantir que a educação seja igual para todos. Tem municípios em que todas as escolas são do campo - sustenta Fabiane [Pres. da UNCME], defendendo que "a recuperação da carga horária seja discutida após a pandemia”. (ENTIDADES..., 2020, n.p.).

Com o passar dos dias, não se vislumbra o retorno massivo dos estudantes para as escolas e se faz necessária a discussão da recuperação e da continuidade das aulas, mesmo sem o fim da pandemia. Face a essas circunstâncias, as mantenedoras das redes públicas de Educação Básica estão construindo protocolos sanitários, orientações legais e pedagógicas para retomar as atividades por meio da educação remota para junho do corrente (2020).

Na live "Pandemia 2020 e Organização Pedagógica das Secretarias de Educação dos Estados" (UNISINOS, 2020), realizada em 14 de maio de 2020, Faisal Karam, Secretário da Educação do Estado do Rio Grande do Sul, divulga que, no retorno das aulas presenciais, será realizada uma avaliação por meio de uma parceria com a Universidade Federal de Juiz de Fora (MG) para avaliar as aprendizagens dos estudantes desenvolvidas no ensino remoto para dar continuidade aos estudos. Será uma avaliação em larga escala? Esse indício pode nos levar a pensar que seriam priorizadas as competências previstas na Base Nacional Comum Curricular (BRASIL, 2018) e no Referencial Curricular Gaúcho (RIO GRANDE DO SUL, 2018) e a avaliação se daria no sentido de verificar seu desenvolvimento, mesmo na contingência da pandemia. 
Se, por um lado, a Secretaria de Educação do RS parece investir na condução de uma conduta dos professores para manter a performatividade no alcance do cumprimento do calendário e do currículo previsto para manter as metas estabelecidas; por outro lado, pesquisadores têm indicado outros caminhos, como na reportagem a seguir:

\begin{abstract}
A socióloga Rita Coelho, que foi coordenadora de Educação Infantil do Ministério da Educação entre 2007 e 2016, disse que fornecer materiais e opções de atividades para as famílias é importante. No entanto, ela disse ver com preocupação que, ao passar a ser contabilizadas para o cálculo das 800 horas, haja uma exigência e cobrança em cima das famílias. "Estamos em uma situação de calamidade, de urgência para as escolas e famílias. Acho mais importante nos preocuparmos em como as crianças estão lidando com essa situação, com o isolamento, com o adoecimento de pessoas próximas. Deveríamos nos preocupar menos com as 800 horas", disse. (SP LIBERA..., 2020, n.p.).
\end{abstract}

De acordo com Veiga-Neto (2012), a racionalidade neoliberal impõe uma crescente necessidade de implantar processos de avaliação nas mais diversas áreas da vida. Estamos imersos, segundo o autor, em delírios avaliatórios que se manifestam no campo educacional pelo crescimento das avaliações de larga escala. "Os delírios avaliatórios manifestam-se tanto pela captura de imensas parcelas da sociedade quanto pelo crédito acrítico que tais parcelas depositam nos resultados estatísticos, em geral expressos em índices cuja metodologia de obtenção e tratamento é quase sempre duvidosa" (VEIGA-NETO, 2012, p. 15). Na esteira de Ball (2005), é possível afirmarmos que a utilização de avaliações em larga escala para verificar as aprendizagens dos alunos durante o período de educação remota está conectada a uma cultura de performatividade que cada vez mais impera nas searas educacionais.

Não estamos negando a necessidade de avaliar o desenvolvimento dos estudantes via atividades remotas. Entretanto, outras condutas podem ser criadas, tais como, em vez de uma instituição externa avaliar os estudantes, os próprios docentes podem fazê-lo priorizando não apenas as competências previstas em documentos oficiais, mas dando uma mais ampla visibilidade ao vivido e ao aprendido neste momento de pandemia, no isolamento social. Assim como Rita Coelho, outros pesquisadores, como Tonnuci (2020) e Dussel (2020), defendem propostas tanto para docência a ser exercida por meio do ensino remoto quanto para o retorno às aulas presenciais que focam na compreensão de como viveram o período, as aprendizagens cotidianas que puderam construir com aqueles que coabitavam o espaço de isolamento social, aprendizagens no cuidado de si e dos outros...

A docência nos tempos de pandemia é uma docência exausta, ansiosa e preocupada. Que quer acertar, mas que avança no meio da incerteza e da adversidade - e que não tem a menor ideia do caminho. Como todos, os professores estão imersos em uma névoa e seguem através dela, buscando fazer o melhor, mas sem garantias.

\title{
Considerações finais
}

Neste período de pandemia, a paralisação das atividades presenciais, na maioria dos casos, não vem se traduzindo como uma paralisação das atividades educativas. As escolas necessitam responder aos imperativos da sociedade de aprendizagem (SIMONS; MASSCHELEIN, 2011) e precisam inventar estratégias que consigam transferir seu funcionamento para dentro da casa de estudantes e professores. Assim, as escolas devem orientar seus professores a inventarem essas estratégias, tendo em vista que, como mostra a empiria desta pesquisa, a maior parte da responsabilidade em lidar com essa questão foi delegada aos docentes de modo individualizado. Nem escolas, nem redes de ensino, conseguiram, em um primeiro momento, desenvolver planejamentos abrangentes e produzir orientações claras sobre como os docentes deveriam 
proceder.

No decorrer desse processo de migração das atividades escolares presenciais para ambientes virtuais, percebemos que diferentemente da EAD, cujo acento se dá nos mecanismos de controle, a análise das notícias selecionadas mostra que a educação remota reforça mecanismos disciplinares. Ainda, há uma celebração desse momento como uma oportunidade de inovação nos modelos de ensino e um afastamento daqueles denominados de tradicionais. Entretanto, nossas análises constaram ainda que a migração das atividades escolares vem manter ou até aprofundar os processos de exclusão, seja de acesso à rede, seja de condição de realização das atividades nas casas dos estudantes e até de sobrevivência, como alimentação.

A responsabilização dos professores tende a fortalecer a intensificação e a autointensificação do trabalho aumentando a exaustão docente. Há um difícil equilíbrio entre continuar as atividades letivas e administrar o momento atual que tem gerado estresse e ansiedade. Orientações dos sindicatos para lidar com a educação exausta foram significadas neste artigo como práticas de contraconduta, no sentido foucaultiano.

Para finalizar e mantendo a atitude crítica, reconhecemos que as práticas de contraconduta são consideradas necessárias na tentativa de conter a exaustão docente. Entretanto, não são entendidas de forma salvacionista, mas paradoxal. Se, por um lado, questionam/limitam as condutas orientadas pelas mantenedoras; por outro, elas as sustentam. Ao priorizar as aprendizagens cotidianas da contingência como conhecimento escolar "dando as costas" para as competências previstas antes da pandemia, continuam a promover aprendizados de leitura, de escrita, de cálculo, de letramentos geográficos, históricos, artísticos, corporais,.. que mantêm o processo de escolarização. Desse modo, não deixam de contribuir para o fortalecimento da performatividade escolar. Se, neste momento, a escola não pode parar, a sua continuidade deve-se ao trabalho docente considerado mais efetivo quando mais se aproximar da lógica que pauta a sociedade $24 / 7$.

\section{Referências}

APPLE, M. Trabalho docente e textos: economia política das relações de classe e gênero. Porto Alegre: Artes Médicas, 1995.

ASSUNÇÃO, A. Á.; OLIVEIRA, D. A. Intensificação do trabalho e saúde dos professores. Educação \& Sociedade, Campinas, v. 30, n. 107, p. 349-372, maio/ago. 2009. DOI: https://doi.org/10.1590/S0101-73302009000200003

BALL, S. Profissionalismo, gerencialismo e performatividade. Cadernos de Pesquisa, São Paulo, v. 35, n. 126, p. 539-564, set./dez. 2005. DOI: http://dx.doi.org/10.1590/S010015742005000300002

BRASIL. Base Nacional Comum Curricular-BNCC. Brasília: MEC, 2018.

COMITÊ INVISÍVEL. Motim e destituição agora. São Paulo: n-1, 2018.

CONSED. Conselho Nacional de Secretários de Educação. Consed lança diretrizes para protocolos de retorno às aulas. CONSED Notícias, 17 jun. 2020. Disponível em: http://www.consed.org.br/portal/noticia/consed-lanca-diretrizes-para-protocolos-de-retornoas-aulas. Acesso em: 10 jul. 2020. 
COSTA, H. O lugar das contracondutas na genealogia foucaultiana do governo. Revista de Filosofia Moderna e Contemporânea, Brasília, v. 7, n. 1, p. 61-78, abr. 2019. DOI: https://doi.org/10.14195/1984-249X 26 10

CRARY, J. 24/7: capitalismo tardio e os fins do sono. São Paulo: Ubu, 2016.

DIÁLOGOS na Pandemia. Educação em tempos de pandemia. Canal Univates, 1 jun. 2020 (127 min). Disponível em: https://www.youtube.com/watch?v $=$ myPm-hU39lw\&feature=youtu.be. Acesso em: 25 jun. 2020.

DUSSEL, I. La classe em pantuflas. Canal do Instituto Superior de Estudios Pedagógicos, 23 abr. 2020 (139min). Disponível em: https://www.youtube.com/watch?v=6xKvCtBC3Vs\&t=3s. Acesso em: 25 jun. 2020.

FAMURS; UDIME; UNCME. Nota conjunta de esclarecimento. 27 mar. 2020. Disponível em: https://undimers.org.br/wp-content/uploads/2020/03/Nota-Conjunta-FAMURS-UNDIME-

UNCME-27-03-2020.pdf. Acesso em: 25 jun. 2020.

FOUCAULT, M. Eu sou um pirotécnico. In: POL-DROIT, R. (org.). Michel Foucault: entrevistas. São Paulo: Graal, 2006. p. 67-100.

FOUCAULT, M. Segurança, território, população. São Paulo: Martins Fontes, 2008.

FOUCAULT, M. Vigiar e punir. Petrópolis, RJ: Vozes, 1999.

FOUCAULT, M. Qu'est-ce que la critique? Critique et Aufklärung. Bulletin de la Société française de philosophie, v. 84, n. 2, p. 35- 63, avril/juin 1990. (Conferência proferida em 27 de maio de 1978).

GI RS. Governo do RS suspende aulas da rede estadual a partir desta quinta devido ao coronavírus. G1 RS, 16 mar. 2020. Disponível em: https://g1.globo.com/rs/rio-grande-dosul/noticia/2020/03/16/governo-do-rs-suspende-aulas-da-rede-estadual-a-partir-desta-quintadevido-ao-coronavirus.ghtml. Acesso em: 25 jun. 2020.

GARCIA, M. M. A.; ANADON, S. B. Reforma educacional, intensificação e autointensificação do trabalho docente. Educação \& Sociedade, Campinas, v. 30, n. 106, p. 63-85, jan./abr. 2009. DOI: https://doi.org/10.1590/S0101-73302009000100004

GUIMARÃES, L. M. S.; SOUZA, M. N. Intensificação do trabalho docente em tempos de coronavírus: uma análise do Programa de Educação a Distância da Rede Estadual de Ensino do Paraná. Instituto de Pesquisa e Planejamento Urbano e Regional da UFRJ, 2020. Disponível em: $\quad$ https://ippur.ufrj.br/index.php/pt-br/noticias/outros-eventos/744-intensificacao-dotrabalho-docente-em-tempos-de-coronavirus-uma-analise-do-programa-de-educacao-a-distanciada-rede-estadual-de-ensino-do-parana. Acesso em: 10 ago. 2020.

HAN, B. C. Sociedade da transparência. Petrópolis: Vozes, 2018.

HARGREAVES, A. Os professores em tempos de mudanças: o trabalho e a cultura dos professores na Idade Moderna. Lisboa: McGraw-Hill, 1998. 
IPOG. Aula remota não é EAD? Entenda as diferenças e todas as vantagens. IPOG, 22 maio 2020. Disponível em: https://blog.ipog.edu.br/educacao/aula-remota/. Acesso em: 25 jun. 2020.

LAZZARATO, M. La fabrique de l'homme endetté. Paris: Amsterdam, 2011.

MÁRQUEZ, G. G. O amor nos tempos do cólera. Tradução de Antonio Callado. 15. ed. Rio de Janeiro: Editora Record, 1995.

PANSOPHIA PROJECT. Onze teses urgentes para uma pedagogia do contra-isolamento. Blog Pensar a Educação, 6 maio 2020. Disponível em: https://pensaraeducacao.com.br/blogpensaraeducacao/onze-teses-urgentes-para-umapedagogia-do-contra-isolamento/. Acesso em: 25 jun. 2020.

PORTO ALEGRE. Decreto $\mathbf{N}^{\mathbf{2}} \mathbf{2 0 . 4 9 9}$, de 16 de março de 2020. Dispõe sobre medidas a serem adotadas para o enfrentamento da emergência de saúde pública decorrente do novo Coronavírus (COVID-19) no Município de Porto Alegre. Porto Alegre: Prefeitura Municipal, [2020a]. Disponível em: https://leismunicipais.com.br/a/rs/p/portoalegre/decreto/2020/2049/20499/decreto-n-20499-2020-dispoe-sobre-medidas-a-seremadotadas-para-o-enfrentamento-da-emergencia-de-saude-publica-decorrente-do-novocoronavirus-covid-19-no-municipio-de-porto-alegre. Acesso em: 25 jun. 2020.

PORTO ALEGRE. Decreto $\mathbf{N}^{\mathbf{0}}$ 20.516, de 20 de março de 2020. Proíbe o funcionamento de padarias restaurantes, bares e lancherias, exceto os estabelecimentos com serviço de tele-entrega, delivery e pegue e leve (take away) no Município de Porto Alegre. Porto Alegre: Prefeitura Municipal, [2020b]. Disponível em: https://www.legisweb.com.br/legislacao/?id=391322. Acesso em: 25 jun. 2020.

RIO GRANDE DO SUL. Governo prorroga suspensão de aulas em todas as instituições de ensino até o fim de abril. Agência de Notícias do Governo, Porto Alegre, 31 mar. 2020a. Disponível em: https://estado.rs.gov.br/governo-prorroga-suspensao-de-aulas-em-todas-as-instituicoes-deensino-ate-o-fim-de-abril. Acesso em: 25 jun. 2020.

RIO GRANDE DO SUL. Decreto $\mathbf{N}^{\mathbf{0}} \mathbf{5 5 . 1 5 4}$, de $\mathbf{1}^{\circ}$ de abril de 2020. Reitera a declaração de estado de calamidade pública em todo o território do Estado do Rio Grande do Sul para fins de prevenção e de enfrentamento à epidemia causada pelo COVID-19 (novo Coronavírus), e dá outras providências. Porto Alegre: Governo do Estado, [2020b]. Disponível em: https://educacao.rs.gov.br/upload/arquivos/202004/01154835-decreto-calamidade-publica1.pdf. Acesso em: 25 jun. 2020.

RIO GRANDE DO SUL. Secretaria de Estado do Rio Grande do Sul. Departamento Pedagógico. União Nacional dos Dirigentes Municipais de Educação. Referencial Curricular Gaúcho. Porto Alegre, 2018. Disponível em: http://curriculo.educacao.rs.gov.br/Sobre/Index. Acesso em 20 jun. 2020.

RIZZINI, I. Meninos desvalidos e menores transviados: a trajetória da assistência pública até a Era Vargas. In: RIZZINI, I.; PILOTTI, F. (orgs.). A arte de governar crianças: a história das políticas sociais, da legislação e da assistência à infância no Brasil. São Paulo: Cortez, 2011. p. 203-221.

SARAIVA, K. Educação a distância: outros tempos, outros espaços. Ponta Grossa/PR: UEPG, 2010. 
SARAIVA, K. Diários de uma pesquisa off-road: análise de textos como problematização de regimes de verdade. In: FERREIRA, T.; SAMPAIO, S. (orgs.). Escritos metodológicos: possibilidades para a pesquisa contemporânea em Educação. Maceió: EDUFAL, 2009a. p.13-34.

SARAIVA, K. Uma educação sem limites. In: REUNIÃO ANUAL DA ANPED, 32., 2009, Caxambu. Anais [...]. Caxambu: ANPED, 2009b. p. 1-14.

SARAIVA, K.; SANTOS, I. M. A internet nasce para todos. Textura, Canoas, n. 19-20, p. 51-64, 2009.

SARAIVA, K.; VEIGA-NETO, A. Modernidade líquida, capitalismo cognitivo e Educação contemporânea. Educação \& Realidade, Porto Alegra, v. 34, n. 2, p. 187-201, maio/ago. 2009.

SILVA, F. T. Currículo de transição: uma saída para a educação pós-pandemia. Revista EDUCAmazônia - Educação Sociedade e Meio Ambiente, Humaitá v. 24, n. 1, p. 70-77, jan./jun. 2020.

SIMONS, M.; MASSCHELEIN, J. Sociedade da Aprendizagem e Governamentalidade: uma introdução. Currículo Sem Fronteiras, v. 11, n. 1, p. 121-136, jan./jun. 2011.

TONUCCI, F. Cuando empecemos de nuevo, deberemos inventar otra escuela. Tiempo, Buenos Aires, 17 maio 2020. Disponível em: https://www.inforegion.com.ar/2020/06/09/cuandoempecemos-de-nuevo-deberemos-inventar-otra-escuela/. Acesso em: 10 ago. 2020.

TRAVERSINI, C. S.; LOCKMANN, K.; GOULART, L. B. Uma ação de contraconduta no currículo para o enfrentamento à distorção idade-série em tempos de neoliberalismo: o Projeto Trajetórias Criativas. E-curriculum, São Paulo, v. 17, n. 4, p. 1566-1586, 2019. DOI: https://doi.org/10.23925/1809-3876.2019v17i4p1566-1586

UNESCO. UNESCO lança publicação com orientações sobre práticas educacionais abertas durante a pandemia. 26 maio 2020. Disponível em: https://nacoesunidas.org/unescolanca-publicacao-com-orientacoes-sobre-praticas-educacionais-abertas-durante-a-pandemia/.

Acesso em: 25 jun. 2020.

UNISINOS. Pandemia 2020 e Organização Pedagógica das Secretarias de Educação dos Estados. Canal Humanidades - UNISINOS, São Leopoldo, 14 abr. 2020 (110min). Disponível em: https://www.youtube.com/watch?v=kC_pHTLk29E. Acesso em 20 jun. 2020.

VEIGA-NETO, A. Currículo: um desvio à direita ou delírios avaliatórios. In: COLÓQUIO SOBRE QUESTÕES CURRICULARES, 10., 2012. Belo Horizonte. Anais [...]. Belo Horizonte: UFMG, 2012. p. 1-17.

VEIGA-NETO, A.; LOPES, M. C. Inclusão, exlusão, in/exclusão. Verve, São Paulo, n. 20, p. 121 135, 2011. 


\section{Referências - material empírico}

97,4\% das escolas privadas usam plataformas online e aplicativos para o ensino remoto. SINEPE/RS, Porto Alegre, 30 abr. 2020. Disponível em: https://www.sinepers.org.br/noticias/974-das-escolas-privadas-usam-plataformas-online-e-aplicativos-para-o-ensinoremoto. Acesso em: 25 jun. 2020.

ATIVIDADES domiciliares: aprendizado e cuidado ou adoecimento? CPERS, Porto Alegre, 9 abr. 2020. Disponível em: https://cpers.com.br/atividades-domiciliares-aprendizado-e-cuidadoou-adoecimento/. Acesso em: 25 jun. 2020.

CANSAÇO e repetição: curso online obrigatório continua dificultando a vida dos educadores. CPERS, Porto Alegre, 8 abr. 2020. Disponível em: https://cpers.com.br/cansaco-e-repeticaocurso-obrigatorio-segue-dificultando-a-vida-dos-educadores-gauchos/. Acesso em: 25 jun. 2020.

CEED/RS publica Parecer autorizando atividades domiciliares. SINEPE/RS, Porto Alegre, 18 mar. 2020. Disponível em: https://www.sinepe-rs.org.br/noticias/ceedrs-publica-parecerautorizando-atividades-domiciliares. Acesso em: 25 jun. 2020.

EDUCAÇÃO A DISTÂNCIA impõe novos desafios às famílias. GAÚCHAZH, Porto Alegre, 1 abr. 2020. Disponível em: https://gauchazh.clicrbs.com.br/geral/noticia/2020/04/educacao-adistancia-impoe-novos-desafios-as-familias-ck8h3b5hv00cb01lbtzxyp3i5.html. Acesso em: 25 jun. 2020 .

EDUCAÇÃO em tempos de zap: pandemia expõe desigualdades sociais e limites do EAD. CPERS, Porto Alegre, 1 abr. 2020. Disponível em: https://cpers.com.br/educacao-em-temposde-zap-pandemia-expoe-desigualdades-sociais-e-limites-do-ead/. Acesso em: 25 jun. 2020.

ELY, Débora. Aulas presenciais nas escolas do RS não têm prazo para retorno. GAÚCHAZH, Porto Alegre, 29 abr. 2020. Disponível em: https://gauchazh.clicrbs.com.br/educacao-eemprego/noticia/2020/04/aulas-presenciais-nas-escolas-do-rs-nao-tem-prazo-para-retornock9lwcmbi00oj017ndtzewi2r.html. Acesso em: 25 jun. de 2020.

EM AUDIÊNCIA, representante da Seduc fala em pelo menos mais "20 dias" de aulas suspensas. CPERS, Porto Alegre, 28 abr. 2020. Disponível em: https://cpers.com.br/em-audienciarepresentante-da-seduc-fala-em-pelo-menos-mais-20-dias-de-aulas-suspensas/. Acesso em: 25 jun. 2020.

ENSINO Remoto Emergencial: a oportunidade da escola criar, experimentar, inovar e se reinventar. SINEPE/RS, Porto Alegre, 17 abr. 2020. Disponível em: https://www.sinepers.org.br/noticias/ensino-remoto-emergencial-a-oportunidade-da-escola-criar-experimentarinovar-e-se-reinventar. Acesso em: 25 jun. 2020.

ENTIDADES ligadas aos municípios gaúchos defendem recuperação presencial das aulas após pandemia. GAÚCHAZH, Porto Alegre, 2 abr. 2020. Disponível em: https://gauchazh.clicrbs.com.br/coronavirus-servico/noticia/2020/04/entidades-ligadas-aosmunicipios-gauchos-defendem-recuperacao-presencial-das-aulas-apos-pandemiack8j4o22200z601o5x6h9lct4.html. Acesso em: 25 jun. 2020. 
FILHOS em casa: como pais devem participar da vida escolar das crianças. SINEPE/RS, Porto Alegre, 20 abr. 2020. Disponível em: https://www.sinepe-rs.org.br/noticias/filhos-em-casacomo-pais-devem-participar-da-vida-escolar-das-criancas. Acesso em: 25 jun. 2020.

FONSECA, C. Escolinhas de Canoas montam drive thru para receber agasalhos e promover reencontro com as "profes". GAÚCHAZH, Porto Alegre, 30 maio 2020. Disponível em: https://gauchazh.clicrbs.com.br/fique-bem/noticia/2020/05/escolinhas-de-canoas-montamdrive-thru-para-receber-agasalhos-e-promover-reencontro-com-as-profesckatzmiog0031015n85prebj6.html. Acesso em: 25 jun. 2020.

HARTMANN, M.; BOFF, T. Aulas a distância aumentam fosso entre escolas públicas e particulares. GAÚCHAZH, Porto Alegre, 17 maio 2020. Disponível em: https://gauchazh.clicrbs.com.br/educacao-e-emprego/noticia/2020/05/aulas-a-distanciaaumentam-fosso-entre-escolas-publicas-e-particulares-ckabhvddv0061015nlc5sjrpe.html. Acesso em: 25 jun. 2020.

JOVENS podem sair do isolamento com mais autonomia para estudar, diz astro do ensino online. GAÚCHAZH, Porto Alegre, 16 abr. 2020. Disponível em: https://gauchazh.clicrbs.com.br/geral/noticia/2020/04/jovens-podem-sair-do-isolamento-commais-autonomia-para-estudar-diz-astro-do-ensino-online-ck929gn6k00vo01p53x8q43o9.html.

Acesso em: 25 jun. 2020.

JUSTINO, G. Após percalços, educação pode ter legado positivo com superação durante a pandemia. GAÚCHAZH, Porto Alegre, 15 maio 2020. Disponível em: https://gauchazh.clicrbs.com.br/educacao-e-emprego/noticia/2020/05/apos-percalcoseducacao-pode-ter-legado-positivo-com-superacao-durante-a-pandemiacka8v2r0o002g015n6h3yarv5.html. Acesso em: 25 jun. 2020.

MEDIDA Provisória suspende a obrigatoriedade dos 200 dias letivos. SINEPE/RS, Porto Alegre, 2 abr. 2020. Disponível em: https://www.sinepe-rs.org.br/noticias/medida-provisoriasuspende-a-obrigatoriedade-dos-200-dias-letivos. Acesso em: 25 jun. 2020.

OCHÔA, V. Quarentena impõe teletrabalho na educação básica. SINPRO/RS, Porto Alegre, 11 abr. 2020. Disponível em: https://www.extraclasse.org.br/educacao/2020/04/quarentena-impoeteletrabalho-na-educacao-basica/. Acesso em: 25 jun. 2020.

OLIVEIRA, R. Estudantes de escolas públicas do Estado terão internet no celular para aulas virtuais. GAÚCHAZH, Porto Alegre, 13 maio 2020. Disponível em: https://gauchazh.clicrbs.com.br/colunistas/rosane-de-oliveira/noticia/2020/05/ estudantes-deescolas-publicas-do-estado-terao-internet-no-celular-para-aulas-virtuais-

cka5xwtol00px015n7q3xjxl6.html. Acesso em: 25 jun. 2020.

RETOMADA das aulas no RS ocorrerá em cinco etapas e pode durar até setembro. GAÚCHAZH, Porto Alegre, 27 maio 2020. Disponível em: https://gauchazh.clicrbs.com.br/coronavirus-servico/noticia/2020/05/retomada-das-aulas-nors-ocorrera-em-cinco-etapas-e-pode-durar-ate-setembro-ckapqyakz00he015nbazmiyzo.html.

Acesso em: 25 jun. 2020. 
SAIBA como as escolas estão desenvolvendo as atividades domiciliares. SINEPE/RS, Porto Alegre, 6 abr. 2020. Disponível em: https://www.sinepe-rs.org.br/noticias/saiba-como-as-escolasestao-desenvolvendo-as-atividades-domiciliares. Acesso em: 25 jun. 2020.

SINEPE/RS esclarece sobre pagamento das mensalidades. SINEPE/RS, Porto Alegre, 1 abr. 2020. Disponível em: https://www.sinepe-rs.org.br/noticias/sinepers-esclarece-sobrepagamento-das-mensalidades. Acesso em: 25 jun. 2020.

SINPRO/RS pede a suspensão imediata das aulas. SINPRO/RS, Porto Alegre, 16 mar. 2020. Disponível em: https://www.sinprors.org.br/comunicacao/noticias/sinpro-rs-pede-a-suspensaoimediata-das-aulas/. Acesso em: 25 jun. 2020.

SP LIBERA atividades a distância na educação infantil na quarentena. GAÚCHAZH, Porto Alegre, 16 abr. 2020. Disponível em: https://gauchazh.clicrbs.com.br/geral/noticia/2020/04/splibera-atividades-a-distancia-na-educacao-infantil-na-quarentenack92r6grd00x901p5azpaan6h.html. Acesso em: 25 jun. 2020.

UNESCO ANUNCIA coalizão para garantir a educação durante o coronavírus. GAÚCHAZH, Porto Alegre, 26 mar. 2020. Disponível em: https://gauchazh.clicrbs.com.br/mundo/noticia/2020/03/unesco-anuncia-coalizao-paragarantir-a-educacao-durante-o-coronavirus-ck88ukary021a01o9152e 5rnt.html. Acesso em: 25 jun. 2020.

Recebido em 02/07/2020

Versão corrigida recebida em 10/08/2020

Aceito em 11/08/2020

Publicado online em 14/08/2020 